\title{
DISCIPLINARY DISTINCTION OR RESPONSIBILITY?
}

\author{
Priscilla S. Rogers \\ University of Michigan
}

\begin{abstract}
"I had become a professor without ever being able to state clearly what it was that I was professing," wrote Fritz Jules Roethlisberger (1977, p. 1), who was instrumental in establishing organizational behavior at the Harvard Business School. "Throughout my career," he continued, "the same old questions reappeared . . . about the nature of the phenomena with which we were concerned and about the relations between theory and practice" $\left(1977\right.$, p. 5). ${ }^{1}$ Long associated with discussions of disciplinarity, issues involving theory and practice are central in the lead articles on business, corporate, management, and organizational communication in this volume. Acknowledging practice, Argenti (1996, p. 82 [this issue]) explains that "[b]ecause of its close connection to the functional area within corporations, corporate communication as an academic discipline has taken on many of the characteristics of the function itself' (emphasis added), and Smeltzer (1996, p. 18 [this issue]) sees management communication as providing "guidelines or prescriptions for implementation." By contrast, here Mumby and Stohl (1996, pp. 56-57 [this issue]) disassociate organizational communication from practical skills, arguing that their disciplinary distinctiveness is to be found in a set of central problematics that free them from "corporate accountability in the sense of producing pragmatic results for managers." Standing somewhere in the middle, Reinsch (1996 [this issue]) presents business communication as practical, but in a higher sense, contributing to the shape, thought, behavior, and sensibilities of a community rather than furnishing trade courses and how-to manuals, all the while cautioning that to
\end{abstract}


neglect either practice or theory can result in trade-school or ivory-tower approaches, either of which distorts a field.

Taking Reinsch's caution as a starting point, this response argues that some of the disciplinary distinctions proposed in this issue's lead articles actually represent aspects of theory or practice that are fundamental to all four fields. Examining what is deemphasized or, in some instances, defined away in these disciplinary definitions suggests areas where attention may be needed. Disciplinary relationships with organizations and disciplinary purpose are of particular interest.

\section{DISCIPLINARY RELATIONSHIPS WITH ORGANIZATIONS: SYMBIOTIC TENSION}

There is likely agreement that some sort of relationship with organizations is necessary for the disciplines of business, corporate, management, and organizational communication alike, although the specific nature of these relationships undoubtedly varies fieldto-field. Disciplinary variations may not be as clear-cut or antithetical as proposed, however. For example, consider Mumby and Stohl's comparison of organizational communication with business, corporate, and management communication in business schools.

Unlike our colleagues in schools of business and management, we do not exist in a symbiotic relationship with the corporate world. . . . [O]ur task is not to engage in research that reflects managerial interests and corporate values, but rather to challenge the prevailing, commonsense notions of the social world, corporate or otherwise. ... [Our role is] cultivating, as opposed to resolving, this tension between the university and the corporate world. (emphasis added, 1996, pp. 56-57 [this issue])

Mumby and Stohl further explain that whereas "business schools and the corporate sector function largely as partners in the task of producing well-trained and productive managers, organizational scholars in departments of communication do not reflect corporate interests in so straightforward a manner" (emphasis added, 1996, p. 57 [this issue]). 
In some respects, Mumby and Stohl's conclusion reflects reality. Fields such as business, corporate, and management communication generally do reside in business schools where professional associations with for-profit and nonprofit organizations are valued, even encouraged. Constantly monitored by business school faculty, these associations are not without continual conflicts (e.g., the current dialogue regarding obsessive recruiting efforts that may be undermining students' business education, vividly headlined on the front page of the December 5, 1995, Wall Street Journal as "To M.B.A. Candidates, The Top Course Today Is to Land a Good Job. . . . But Education May Suffer"). At the same time, Mumby and Stohl's conclusion raises troubling questions, particularly for those working in the disciplines relegated as "partners." Does the fact that academics in business schools serve as consultants, work to gain access to organizations, and teach individuals who assume or hold positions in for-profit or nonprofit organizations imply a partnership that compromises scholarly integrity, prevents objective observation, or nullifies the ability to critique? Is the necessary tension between a discipline and the world it observes compromised by a "symbiotic relationship," an "intimate living together?"2 Does an acknowledged interdependence negate a discipline's ability to challenge?

The idea that symbiotic relationships with organizations hinders or in some way perverts honorable disciplinary knowledge building is questionable. As the word implies, disciplinary membership involves discipline. Research methodologies are a case in point. Even ethnographers, who to varying degrees live in the worlds they study, must meet rigorous standards of observation, incorporating principles of triangulation by collecting several kinds of data that are compared, cross-checked, and reevaluated to corroborate inferences and to ensure authenticity and objectivity (Cross, 1994; Saville-Troike, 1982). As Fetterman (1989) observed: “[E]thnographers are noted for their ability to keep an open mind about the group or culture they are studying" (p. 11). If the participant observer follows sound methodological procedures, the disciplinary community places confidence in the results. Although ethnographers and other investigators are not immune to influences or 
vested interests, methodological norms allow academicians to "make strange" (Mumby \& Stohl, [this issue]) what is observedto be in the world but not of that world (Smeltzer, [this issue]).

Taking the issue of relationship even further, consider Smeltzer's question here: "[H]ow can the university professor understand which knowledge is correct when [he or she has] not lived in that world?" (1996, p. 14 [this issue]). In fact, can an academic in business, corporate, management, or even organizational communication truly challenge organizations without knowing them from the inside out? Is it possible to foster a meaningful tension between the university and the corporate world without intimately understanding the contexts, cultures, and rules underlying events and interactive processes in play? Without knowing organizations from the inside out, our disciplines risk being "dominated by the scenes in which we live" (Kent, 1994, p. 154); being inbred, self-perpetuating, out-of-touch, and irrelevant at a time when, as Kennedy (1993) observed, it is "very difficult to justify holding the place of a tired discipline against hale and hearty claimants for admission" (p. 137). Symbiotic relationships with organizations and the multiple individuals who comprise them may be inherent to sound disciplinary work.

Furthermore, the fields of business, corporate, management, and organizational communication may be accountable to organizations. Applying Rosovsky's (1990) notion that colleges and universities have multiple "owners" (e.g., faculty, administrators, students, alumni, donors, communities, the press, and government agencies), one could argue that academic accountability to the corporate sector is also a reality not an option, even for those whose disciplinary homes reside outside business schools. As new kinds of alliances between the academy and the workplace proliferate, as technological advances invite unique venues of interaction, and as corporations, intent on becoming learning organizations, offer competitive opportunities (Casper, 1995; Senge, 1990), the ivory tower becomes more and more obsolete. Indeed, can our disciplines grow stronger and remain viable without interested and challenging partners outside academe? Perhaps rather than cultivating symbiotic relationships, our times call for partnerships with organizations 
that are characterized by a symbiotic tension of mutual exchange and critique: a kind of separate-but-equal living together with mutuality and respect that facilitates challenge giving and challenge receiving.

\section{DISCIPLINARY PURPOSE: RELEVANCE RATHER THAN PRESCRIPTION OR ELITISM}

Closely tied to relational issues are concerns that our disciplines may lack relevance-concerns that undoubtedly have prompted calls for a kind of disciplinary pragmatism. For example, Argenti suggests here that corporate communication's further development as a field should positively influence the practices of corporations in dealing with identity, crises, and other issues. Taking a similar concern even further, Smeltzer challenges management communication academics to write articles practitioners actually read, by streamlining the research process to ensure publication before organizations develop "their own models and styles through trial and error," (1996, p. 16 [this issue]) by focusing on results-oriented research with practitioner appeal, and by developing a common vocabulary to assure the nuances of the research are fully understood by practitioners. Granted, a disciplinary community may produce a lot of verbiage, signifying little or nothing. As Nobel Prize-winning physicist Richard Feynman observed, disciplinary work can at times seem completely un-understandable, vague and indefinite, something correct that is obvious but worked out by a long and difficult analysis, an attempt to do something impossible or of no utility, or just plain wrong $(1988$, p. 91$)$. And yet, is it not just plain wrong to devalue disciplinary discourse? Should academics concern themselves with Limerick's (1993) criticism that "colleges and universities are filled with knowledgeable, thoughtful people who have been effectively silenced by an artful writing style?"

As Mumby and Stohl here observe of organizational communication, disciplinary practice in all fields involves belonging to a community that sees "objects of study in similar ways, use[s] the 
same 'language game' in describing these phenomena," develops theories "out of a common set of epistemological, ontological, and methodological assumptions," and imposes "standards about what 'counts' as a contribution to that community's body of knowledge." In the best of all disciplines, specialized genres (e.g., working papers, conference proceedings, presentations, and journal articles) comprising conventions of argument, evidence, diction, style, and documentation become a means to prevent some less important ideas from dominating the conversation (Weick, 1995; see also Swales, 1990). This collaborative enterprise of review, reflection, revision, and reward ensures that ideas are honed, tested, and refined. ${ }^{3}$ Its sophistication evidences disciplinary maturity (Carter, 1990; Russell, 1991). Argenti's call for corporate communication to develop a strong research base, Mumby and Stohl's desire for a home journal, Reinsch's concern that business and management communication journals be listed in the Social Sciences Citation Index (Reinsch \& Reinsch, 1996), and Smeltzer's desire for benchmarking studies and research with effectiveness as a dependent variable, all convey a desire to further develop and refine the conventions and instruments of specialized discourse in our fields.

On the other hand, does the need for specialized disciplinary discourse eliminate the task of producing pragmatic results for organizations? Is disciplinary responsibility to the disciplinary community alone? Can Smeltzer's call for pragmatic results be ignored or dismissed as belonging to another communication field, preferably in a business school? According to Mumby and Stohl's article, pedagogy in organizational communication is oriented toward theoretical and research issues rather than pragmatic issues in the corporate context. The chief concern of organizational communication, they contend, "is not with how participatory practices can improve organizational efficiency ... but rather with how a communication approach to workplace democracy can enhance our senses of community and identity" (emphasis added, Mumby \& Stohl, 1996, p. 67 [this issue]). But can concerns regarding organizational efficiency remain outside the interests of academicians in organizational communication or, for that matter, any of the fields under discussion? By only talking with each other, how can aca- 
demics test claims, such as the notion that workplace democracy is the only mode of organizing or that a sense of community and identity is always meaningful and desirable in organizational life?

"In the profession," wrote Altick (1975) of literary research, "there is a pernicious snobbery which demotes the scholar who seeks a wider public to the status of 'popularizer'-ugly word.... Although to popularize may mean to vulgarize, it need not, and it should not" (p. 230). Indeed, in some respects, our disciplines seem intent on running away from any association with pragmatic outcomes or popularity. This tendency stems partially from pressures within the academy. As Kent (1994) observed, our disciplinary constraints are not only epistemological, but political. Interdisciplinarity is discounted and specialization privileged to meet institutional demands. Undoubtedly, the fact that our disciplines incubated in practice also contributes to this flight from associations with anything too practical-addressing communication skills or undertaking some types of applied research may seem like stepping backwards. What Redding (1992) documented of organizational communication could be said of business, corporate, and management communication as well:

Here is a field of study ... whose very raison d'etre induced its practitioners to devote their energies (a) to skills instruction, and (b) to the conduct of "applied" research. Hence, historically speaking, it has been uncommonly difficult for specialists in organizational communication to shift their conceptual gears from low to high, from the pragmatic to the theoretical. (p. 90)

The idea that skills rank low and theory high in the academy and that our disciplines continue to draw theory from other fields may explain to some extent that sense of urgency toward theory building (Redding, 1992; Shelby, 1993). Academe continues to reward research at the beginning of the knowledge curve and borrowing theory from other fields is not beginning. Or is it? Even if we agree with University of Michigan President James Duderstadt (1996) that disciplinary configurations are changing and "those who are at the cutting edge of their fields are often those who travel across them" (p. 18), the need for independent disciplinary recognition may inhibit our fields for some time. 
Yet it may be time to reconsider practice. "Speaking to practice," as Weick (1995) defines it, is not "dumping down, mouthing simple cliches, or teaching the obvious" (p. 3), but rather it is sharing hard-won, profound simplicity that comes by struggling with the tug between generality and accuracy. Further borrowing Weick's words, speaking to practice is grounded in experience, trial and error, failure, reflection, skepticism, resilience, and humility (Weick, 1995, p. 5). For the fields of business, corporate, management, and organizational communication, speaking to practice need not involve a return to disciplinary infancy, associated with vocational-type training and formulaic notions of correctness. Rather, speaking to practice involves addressing the day-to-day functions, concerns, and needs of people working within organizations through both research and teaching. The risk of ignoring practice may be irrelevance.

\section{CONCLUSION}

Disciplinary descriptions of business, corporate, management, and organizational communication both here and in other publications over the last decade (e.g., Redding, 1992; Rentz, 1993; Smeltzer \& Suchan, 1991; Tabeaux \& Killingsworth, 1994) reveal a shared and ongoing discontentment. Not recognizing what has been accomplished explains this discontentment to some degree. Simply thumbing through recent issues of The Academy of Management Journal, Administrative Science Quarterly, Discourse and Society, Human Resource Management Journal, Journal of Business Communication, Journal of Business and Technical Communication, Management Communication Quarterly, and other home journals for business, corporate, management, and organizational communication research provides sufficient evidence to claim that none of these fields focuses almost entirely on skills, none speaks with a "monolithic managerial voice" excluding other voices in organizational life, and none of these fields lacks content. Even as a new disciplinary entrant, corporate communication, enjoys a growing body of research (e.g., Larwood, Falbe, Kriger, \& Miesing, 
1995; Seiter, 1995; Stratman, Boykin, Holmes, Laufer, \& Breen, 1995; Swales \& Rogers, 1995; Thralls, 1992b; Tyler, 1992; Vaughn, 1995; see also research cited in Argenti, 1994). Business, management, and organizational communication draw from established literature comprising rigorous quantitative and qualitative work (e.g., Reinsch \& Lewis, 1993). In addition, as Argenti, Mumby and Stohl, Reinsch, and Smeltzer's valuable historical overviews show, the "blood lines" of all four disciplines are substantial and respectable. The fact that all are born of practice and all have grown by feeding on the theoretical fruit of other fields may prove advantageous in this "new era of fundamental change in higher education" (Duderstadt, 1996, p. 5), with increasing respect for interdisciplinary work and new concerns as communication goes more and more digital. Today, business, corporate, management, and organizational communication are marching rather than "stumbling toward identity" (Redding, 1985).

Reinsch's marching orders are: "Get to work" (1996, p. 44 [this issue]). The difficult question is: Get to work at what? Disciplinary discussions here and elsewhere suggest a next step could involve getting further acquainted with the substantial intellectual content available to all four fields. Both research and pedagogical developments have yet to be tapped. For example, corporate communication specialists might compile research covering the topical areas Argenti associates with the field, perhaps undertaking a study similar in its rigor to the Reinsch and Lewis (1993) examination of citation references, only covering a range of publications (see also Reinsch \& Reinsch, 1996). Or business communication scholars may want to articulate (even claim) a research tradition that transcends disciplinary barriers, building on Locker's (1994) vision of interdisciplinarity. For such an undertaking, recent dissertations in composition, computer information systems, organizational behavior, and linguistics may prove an interesting place to begin, perhaps as evidence that $\mathrm{Ph} . \mathrm{D}$. work in business communication does exist in an interdisciplinary sense.

Another task, which has been the focus of this response, involves scrutinizing current disciplinary efforts for areas where theory or 
practice may suffer from neglect. For example, academics in organizational communication may wish to explore whether the "heavily theoretical approach that teaches students to question how organizations function" (Mumby \& Stohl, 1996, p. 54 [this issue]) can continue to exclude "how participatory practices can improve organizational efficiency" (Mumby \& Stohl, p. 67 [this issue]). Perhaps organizational functions and organizational efficiency are inherently linked; perhaps this linkage has everything to do with improving people's quality of life, a primary concern of this field (Mumby \& Stohl, [this issue]). ${ }^{4}$ By contrast, management communication could more deliberately integrate theoretical work into current pedagogical achievements (Munter, 1995). For instance, Orlikowski and Yates's (1994) notion of genre repertoire could inform analyses of cases involving communication media choice and timing; David and Baker's (1994) application of compliance-gaining theory should replace the bad news formula.

All in all, disciplinary identity cannot be found by assigning some facets of practice to another field or by overemphasizing practice to the detriment of disciplinary discourse. In the life of a discipline, there occur shifts; practice may be privileged at one point, theory at another. Sustained emphasis on either practice or theory may very well stifle disciplinary development, however.

\section{NOTES}

1. Similarly, Cambridge philosopher Alfred North Whitehead (1929) wrote: "Science is a river with two sources, the practical source and the theoretical source. The practical source is the desire to direct our actions. . . . The theoretical source is the desire to understand" (pp. 103-104).

2. The second edition of Webster's New World Dictionary (1974) defines "symbiosis" as "the intimate living together of two kinds of organisms, especially where such association is of mutual advantage" (p. 1442).

3. Thralls's (1992a) study of the collaboration between authors, journal editors, and reviewers suggests some of the realities and complexities involved in disciplinary collaborations.

4. Headlines continue to suggest as much: "More Than 43 Million Jobs Lost, Reaching Every Walk of Life," reported the March 3, 1996, New York Times. 


\section{REFERENCES}

Altick, R. D. (1975). The art of literary research. New York: Norton.

Argenti, P. A. (1994). Corporate communication. Boston: Irwin.

Argenti, P. A. (1996). Corporate communication as a discipline: Toward a definition. Management Communication Quarterly, 10, 73-97.

Carter, M. (1990). The idea of expertise: An exploration of cognitive and social dimensions of writing. College Composition and Communication, 41, 265-286.

Casper, G. (1995, April). Come the millennium, where the university. Paper presented at the Annual Meeting of the American Educational Research Association, San Francisco, CA.

Cross, G. A. (1994). Ethnographic research in business and technical writing: Between extremes and margins. Journal of Business and Technical Communication, 8, 118-134.

David, C., \& Baker, M. S. (1994). Rereading bad news: Compliance-gaining features in management memos. Journal of Business Communication, 31(4), 267-290.

Duderstadt, J. J. (1996). Toward an educational transformation. Ann Arbor: University of Michigan.

Fetterman, D. M. (1989). Ethnography: Step by step. Newbury Park, CA: Sage.

Feynman, R. P. (1988). "What do you care what other people think?" Further adventures of a curious character. New York: Norton.

Kennedy, D. (1993). Making choices in the research university. Journal of Academy of Arts \& Sciences, 122(4), 127-156.

Kent, T. (1994). Interdisciplinary research and disciplinary toleration: A reply to Kitty Locker. Journal of Business Communication, 31(3), 153-155.

Limerick, P. N. (1993, October 31). Dancing with professors: The trouble with academic prose. New York Times Book Review, pp. 22-24.

Larwood, L., Falbe, C. M., Kriger, M. P., \& Miesing, P. (1995). Structure and meaning of organizational vision. The Academy of Management Journal, 38(3), 740-786.

Locker, K. O. (1994). The challenge of interdisciplinary research. Journal of Business Communication, 31(2), 137-151.

Lyons, P.J.L., \& Barbanel, J. (1996, March 3, 15). More than 43 million jobs lost, reaching every walk of life. The New York Times.

Mumby, D. K., \& Stohl, C. (1996). Disciplining organizational communication studies Management Communication Quarterly, 10, 50-72.

Munter, M. (1995). Management communication: Business administration reading lists and course outlines (Vol. 16). Chapel Hill, NC: Eno River Press.

Orlikowski, W. J., \& Yates, J. (1994). Genre repertoire: The structuring of communicative practices in organizations. Administrative Science Quarterly, 39, 541-574.

Redding, C. W. (1985). Stumbling toward identity: The emergence of organizational communication as a field of study. In R. D. McPhee \& P. K. Tompkins (Eds.), Organizational communication: Traditional themes and new directions (pp. 15-53). Beverly Hills, CA: Sage.

Redding, C. W. (1992). Response to Professor Berger's essay: Its meaning for organizational communication. Communication Monographs, 59, 87-93.

Reinsch, N. L., Jr. (1996). Business communication: Present, past, and future. Management Communication Quarterly, 10, 27-49.

Reinsch, N. L., Jr., \& Lewis, P. V. (1993). Author and citations patterns for the Journal of Business Communication, 1978-1992. Journal of Business Communication, 30, 435-462. 
Reinsch, N. L., \& Reinsch, J. W. (1996). Some assessments of business communication research from social science citations. Journal of Business and Technical Communication, 10, 28-47.

Rentz, K., (Ed.). (1993). Negotiating the field of business communication [Special issue]. Journal of Business Communication, 30(3), 233-352.

Roethlisberger, F. J. (1977). The elusive phenomena. Boston: Harvard University Press.

Rosovsky, H. (1990). The university: An owner's manual. New York: Norton.

Russell, D. R. (1991). Writing in the academic disciplines. 1870-1990: A curricular history. Carbondale, IL: Southern Illinois University Press.

Saville-Troike, M. (1982). The ethnography of communication: An introduction. New York: Basil Blackwell.

Senge, P. M. (1990). The fifth discipline: The art and practice of the learning organization. New York: Doubleday Currency.

Seiter, J. S. (1995). Surviving turbulent organizational environments: A case study examination of a lumber company's internal and external influence attempts. Journal of Business Communication, 32, 363-382.

Shelby, A. N. (1993). Organizational, business, management, and corporate communication: An analysis of boundaries and relationships. Journal of Business Communication, 30(3), 241-267.

Smeltzer, L. R. (1996). Communication within the manager's context. Management Communication Quarterly, 10, 5-26.

Smeltzer, L. R., \& Suchan, J. E. (Eds.). (1991). Theory building and relevance [Special issue]. Journal of Business Communication, 28(3), 181-299.

Stratman, J. F., Boykin, C., Holmes, M. C., Laufer, M. J., \& Breen, M. (1995). Risk communication, metacommunication, and rhetorical stases in the Aspen-EPA superfund controversy. Journal of Business and Technical Communication, 9, 5-41.

Swales, J. M. (1990). Genre analysis. Cambridge: Cambridge University Press.

Swales, J. M., \& Rogers, P. S. (1995). Discourse and the projection of corporate culture: The mission statement. Discourse \& Society, 6(2), 223-242.

Tabeaux, E., \& Killingsworth, M. J. (Eds.). (1994). Social and historical perspectives on business and technical communication [Special issue]. Journal of Business and Technical Communication, 8(1), 3-147.

Thralls, C. (1992a). Bakhtin, collaborative partners, and published discourse: A collaborative view of composing. In J. Forman (Ed.), New visions of collaborative writing. New Hampshire: Boynton/Cook.

Thralls, C. (1992b). Rites and ceremonials: Corporate video and the construction of social realities in modern organizations. Journal of Business and Technical Communication, 6(4), 381-402.

Tyler, L. (1992). Ecological disaster and rhetorical response: Exxon's communications in the wake of the Valdez spill. Journal of Business and Technical Communication, 6(2), 149-171.

Vaughn, M. A. (1995). Organization symbols: An analysis of their types and functions in a reborn organization. Management Communication Quarterly, 9(2), 219-250.

Weick, K. E. (1995, August 7). Speaking to practice: The scholarship of integration. Invited address to Organizational Behavior Division, National Academy of Management, Vancouver, British Columbia, Canada.

Whitehead, A. N. (1929). The aims of education. New York: Macmillan. 